\title{
Automation of a dynamic system with computer simulation of heat losses
}

\author{
Aleksandr V. Pilipenko ${ }^{1, *}$, Sergey P. Petrov ${ }^{1}$, and Olga V. Pilipenko ${ }^{1}$ \\ ${ }^{1}$ Federal State Budgetary Educational Institution of Higher Education «Orel State University named after I.S. Turgenev», Department of \\ Automated Control Systems and Cybernetics, Orel, Russia
}

\begin{abstract}
The article describes approaches to automation of a non-linear system, the stability of which essentially depends on the impact of external factors and requires compliance with high safety standards. The authors model the processes occurring in the system, substantiate the selection of the equipment. In the paper, the authors take into account (with accepted admissions) the heat losses in the pipes.
\end{abstract}

\section{Introduction}

Recently, heating of apartment buildings has been realized using stand-alone or roof-mounted gas boiler houses, the uninterrupted operation of which is ensured by the fulfillment of a number of requirements described in the normative documents $[1,2]$ and the rules for the installation of electrical stations. One of the important requirements in the design of modern boiler houses is the lack of maintenance personnel. At the same time, an increasingly important role is played by a two-level automation system of the boiler house, which consists of a remote control system for boiler and local automation installed on boilers and control panels.

Two-level automation of important and dangerous objects can reduce labour costs and increase energy efficiency, but it does not improve reliability and safety of the system, which makes it difficult to transfer the system to automatic mode.

According to the Federal Target Program "Reducing Risks and Mitigating the Consequences of Natural Disasters in the Russian Federation until 2020," the reduction in the risks of emergencies of all types and scales and their negative consequences will be achieved through the implementation of the following key areas:

systemic research and improvement of organizational management bases in the field of increasing safety and security of critical facilities against threats of anthropogenic nature;

systemic studies aimed at creating scientific basis for determining the patterns of occurrence of emergencies and management of these risks;

development of infrastructure for information situation analysis of emergency situations.

In this regard, the development of a three-level automated boiler management system with an auxiliary industrial safety management system is an urgent scientific and technical task.

\section{Conception}

The basic two-level system provides cheap automation of technological equipment and technological processes due to PID TPM regulators of OVEN company, additional technological devices of control, data collection, signaling and indication $[3,4]$. This connection allows manual controlling of each boiler separately, if necessary, but also programmatic controlling of all boilers from the control panels (local and remote), by connecting regulators, a modem, a dashboard and a monitor to an industrial controller [5].

Thus, the automation shields of hot-water boilers perform the following functions [6]:

- exclusion of pulsation during ignition of the boiler due to delay;

- control of gas burners;

- control of the recirculation pump;

- diagnostics of the equipment status of the switchboard and sensors;

- heating the boiler during the initial start-up;

- blocking the operation of the boiler in case of emergency high values of the sensors;

- keeping a log of boiler failures;

- filtration of operation of discrete sensors;

- issuance of alarm signals of the boiler to the general boiler board of automation.

The control panel of general boiler equipment provides the following functions $[7,8]$ :

- PID control to maintain the set temperature of the heating circuit;

- calculation of the heating circuit settings by comparing the temperature sensor data and the temperature mode models;

- automatic and manual switching to night / day mode;

- automatic control of the pumps taking into account the worked time;

\footnotetext{
* Corresponding author: a@pilipenko.info
} 
- prohibition of starting boilers with pumps disconnected;

- light and sound indication of emergency parameters of the boiler room;

- diagnostics of the state of the shield equipment and temperature sensors;

- issuing alarms to the controller's panel via GSMcommunication.

The auxiliary control system (subsystem of the third level) of industrial safety is built on a more efficient NI CompactRIO controller and works in parallel with the main two-level system in real time, and also contains the software modules realizing [9]:

- computer models of the state of boilers (dangerous and non-hazardous);

- models of situations exceeding the level of security in both statics and dynamics;

- algorithms for processing sensor data for modeling;

- decision-making algorithms;

- algorithms for working with the knowledge base.

The auxiliary system performs the following functional:

- continuous automatic monitoring of the water temperature at the boiler inlet;

- continuous automatic monitoring of the water temperature at the outlet from the boiler;

- continuous automatic control of water pressure at the boiler inlet;

- continuous automatic control of water pressure at the boiler outlet;

- continuous automatic monitoring of water pressure at the output of charging, main pumps and hot water pumping stations;

- continuous automatic control of the operation of executive mechanisms and devices;

- continuous automatic control of the operation of regulators and PLC-100;

- continuous automatic monitoring of the concentration of carbon monoxide in the boiler room;

- continuous automatic monitoring of the concentration of carbon monoxide in the boiler room;

- continuous automatic control of the concentration of carbon dioxide;

- collection and backup of all data, including data passing through the rs485 buses connected to the OVEN PLC-100.

\subsection{Designing}

As described above, the system consists of three subsystems, with standard requirements for reducing costs and increasing reliability. The lower level of automation is represented by a combination of the OVEN TPM 132 PID controller, two-channel OVEN TPM 202 meter, frequency converters, chokes/valves, sensors and the OVEN IP320 control panel $[10,11]$. The general scheme for connecting devices to the cabinet is shown in Figure 1, where: $1-5$ are temperature sensors; 6 and 7 are solenoid valves; 8 and 9 are frequency converters and motors; 10 and 11 are high-pressure sensors; RS is data bus line RS-485.
The second level of automation should provide local and remote dispatching, maintaining an archive, changing the regimes common to all boilers (summer/winter, day/night), etc. Thus, it was decided to use OVEN PLK-100, TPM 148, MT6070ip operator panel, data transmission module via SHMR-16U radio channel, analog input module MB110-8A. Moreover, during the commissioning of the automated system, such an algorithm for checking the data transmission module over the radio channel was developed, which not only shows the level of the signal, but also the passage of packets along the path:

- install a jumper RX-TX on the maintained ShMP16 ;

- connect a main one to the computer via RS485 or RS232;

- in the PLConnect program, select "main", set the mode of the port, set the "echo mode" and the desired packet p-p (for your case, 60-100 bytes);

- start the exchange and see the quality of the packets passing (about 100\% with good connection).

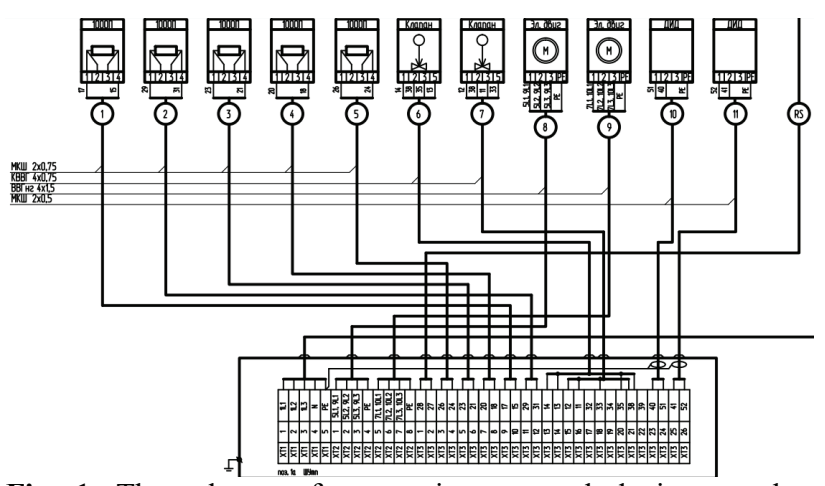

Fig. 1. The scheme of connecting external devices to the control panel.

The auxiliary system (a subsystem of the third level) of industrial safety requires computing power to operate in real or near real time mode, because it produces a solution of differential equations, which are models of the behavior of the system or regulatory object [12]. This system is built on a modular industrial controller NI CompactRIO with analog and digital input and output modules, which allows connecting all sensors and actuators (frequency converters and relays) directly.

\subsection{Modelling}

Types of models used in the algorithms of this automated system can be divided into two:

- mathematical models described by differential equations;

- behavioral models based on sets of settings, embedded in the structure of multiple choice Case.

The use of mathematical equations can be seen in the example of using the heat loss model in the system to calculate the correction coefficients of temperature measurements.

When performing the parametric synthesis of the control system of temperature regime (CSTR), an important step is to determine the boundary conditions within which the synthesis is performed $[13,16]$. 
The basis of the synthesis is the description of the control system by one of the known operators, for example, by differential equations or transfer functions. In the latter case, an operator method is used, which makes it possible to determine the generalized transfer function of the control system (CS) and its characteristic equation $[14,15]$.

Developed in accordance with the new approach $[15,17]$, the CSTR includes a number of subsystems, the main role of which belongs to the subsystem for controlling the final consumer of thermal energy, since it is here that the dynamics of the transient process is determined under the influence of disturbing factors, in particular, from the change in the outdoor air temperature $[13,18,19]$. The dynamic characteristics of the automation object are key when determining the boundary conditions and performing the parametric synthesis of the CSTR. The operator model of the automation object is shown in Figure 2.

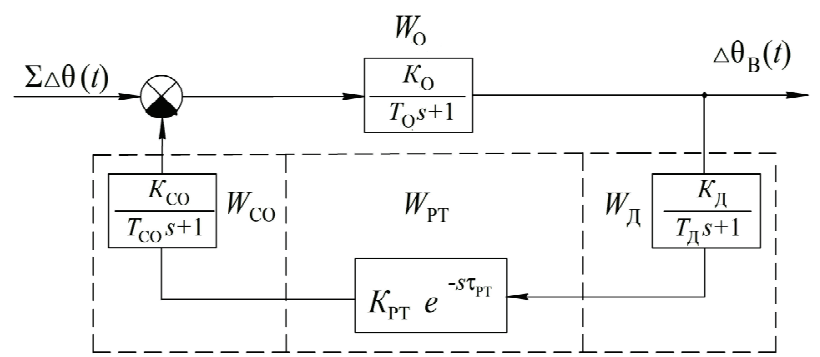

Fig. 2. Operator model of the automation object.

The expression of the transfer function is received according to the operator model of the automation object:

$$
W(s)=\frac{\frac{K_{\mathrm{O}}}{T_{\mathrm{O}} \cdot s+1}}{1+\frac{K_{\mathrm{O}} \cdot K_{\text {д }} \cdot K_{\mathrm{PT}} \cdot K_{\mathrm{CO}}}{\left(T_{\mathrm{O}} \cdot s+1\right) \cdot\left(T_{\text {д }} \cdot s+1\right) \cdot\left(T_{\mathrm{CO}} \cdot s+1\right)} e^{-s \tau_{\mathrm{P \textrm {r }}}}}
$$

where $K_{\mathrm{O}}, \quad K_{\text {со }}, K_{\text {д }}, \quad K_{\text {Рт }}$ are the coefficients of transmission of the automation object, the heating system (warming), sensors, temperature controller; $T_{\mathrm{O}}$, $T_{\mathrm{CO}}, T_{\text {д }}$ are time constants of the automation object, heating system (warming), sensors; $\tau_{\mathrm{PT}}$ is time delay temperature regulator; $S$ is Laplace.

In the stability area, we consider stability at the boundary of aperiodicity, when all the roots of the characteristic equation are negative real $(\alpha<0, \omega=0)$, and on the stability boundary, when the roots of the characteristic equation are complex with negative real $\operatorname{part}(\omega>0, \alpha=0)[15,20]$.

Let us determine the dynamic characteristics of the object of automation, which ensure the stable operation of the CSTR on the stability boundary. The investigation of the control subsystem is performed for a system in which there is a delay associated with the time of movement of the regulating organ. To investigate the behavior of the CSTR with delay at the stability boundary, the characteristic equation is considered for a purely imaginary root value, i.e. when $S=j \omega$, where $0 \leq \omega \leq \infty$.

When the $S_{\text {operator is replaced by a complex }}$ variable $j \omega$, the dependences $K_{\mathrm{o}}=f_{5}\left(T_{\mathrm{O}}\right)$, $K_{\mathrm{o}}=f_{6}\left(T_{\mathrm{CO}}\right), K_{\mathrm{o}}=f_{7}\left(T_{\text {д }}\right), K_{\mathrm{o}}=f_{8}\left(\tau_{\text {Pт }}\right)$ on the stability boundary are obtained [1]:

$$
\begin{aligned}
& T_{\mathrm{O}}=\frac{\left(T_{\text {д }} T_{\mathrm{CO}} \omega-\frac{1}{\omega}\right) \operatorname{tg} \omega \tau_{\mathrm{PT}} T_{\text {д }}-T_{\mathrm{CO}}}{1-T_{\text {д }} T_{\mathrm{CO}} \omega^{2}-\left(T_{\text {д }}+T_{\mathrm{CO}}\right) \omega \operatorname{tg} \omega \tau_{\mathrm{PT}}} ; \\
& T_{\mathrm{CO}}=\frac{\left(T_{\text {д }} T_{\mathrm{O}} \omega-\frac{1}{\omega}\right) \operatorname{tg} \omega \tau_{\mathrm{PT}} T_{\text {д }}-T_{\mathrm{O}}}{1-T_{\text {д }} T_{\mathrm{O}} \omega^{2}-\left(T_{\text {д }}+T_{\mathrm{O}}\right) \omega \operatorname{tg} \omega \tau_{\mathrm{PT}}} ; \\
& T_{\text {д }}=\frac{\left(T_{\mathrm{O}} T_{\text {ОП }} \omega-\frac{1}{\omega}\right) \operatorname{tg} \omega \tau_{\mathrm{PT}} T_{\mathrm{O}}-T_{\text {ОП }}}{1-T_{\mathrm{O}} T_{\text {ОП }} \omega^{2}-\left(T_{\mathrm{O}}+T_{\text {ОП }}\right) \omega \operatorname{tg} \omega \tau_{\mathrm{PT}}} ; \\
& \tau_{\mathrm{PT}}=\frac{1}{\omega} \operatorname{arcrc} \frac{\left(T_{\mathrm{O}}+T_{\text {Д }}+T_{\mathrm{CO}}\right) \omega-T_{\mathrm{O}} T_{\text {Д }} T_{\mathrm{CO}} \cdot \omega^{3}}{\left(T_{\mathrm{O}} T_{\mathrm{CO}}+T_{\text {д }} T_{\mathrm{CO}}+T_{\text {Д }} T_{\mathrm{O}}\right) \omega^{2}-1}
\end{aligned}
$$

The notation for the coefficients entering into formulas $(2 \ldots \ldots 5)$ is given in formula (1). The dependences $K_{\mathrm{o}}=f_{5}\left(T_{\mathrm{o}}\right), \quad K_{\mathrm{o}}=f_{6}\left(T_{\mathrm{CO}}\right)$,

$K_{\mathrm{o}}=f_{7}\left(T_{\text {д }}\right), K_{\mathrm{o}}=f_{8}\left(\tau_{\text {Pт }}\right)$, obtained at the stability boundary, were investigated, and it was established that the maximum transmission coefficient of the CSTR at the stability boundary is much larger than at the aperiodicity boundary. Moreover, for $K_{\mathrm{o}}=f_{5}\left(T_{\mathrm{O}}\right)$ and $K_{\mathrm{O}}=f_{6}\left(T_{\mathrm{CO}}\right)$, this excess is correspondingly 5 and 10 times, respectively. For $K_{\mathrm{o}}=f_{7}\left(T_{\text {д }}\right)$ and $K_{\mathrm{o}}=f_{8}\left(\tau_{\mathrm{PT}}\right)$, this excess is 30 and 10 times.

\subsection{Algorithmization and programming}

All three described subsystems work on algorithms of two types: an algorithm for keeping the minimum and maximum values of set points; an algorithm for keeping the difference in the results of computer simulation and the results of the real operation of the system within the given hysteresis. In the first case, 4 set points are set for each sensor, which determine the inclusion of the regulating bodies, and in the second case a sophisticated algorithm for analyzing deviations from the computer model based on trained neural networks is used. The MS SQL database is connected in the industrial safety management subsystem. The block diagram of the subprogram responsible for interaction with the database using the NI LabVIEW Data Base Connectivity Toolkit is shown in Figure 3. 


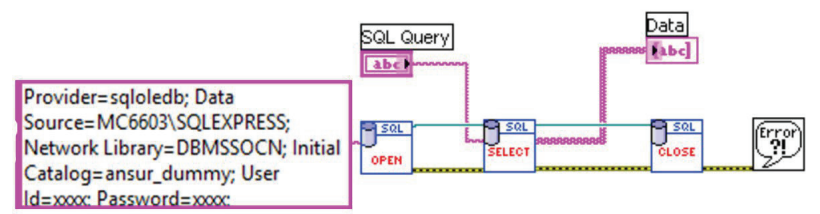

Fig. 3. Block diagram of the subprogramme responsible for interaction with the database.

The requirement for a system to work in close to real time causes problems with processing super-large data sets. In this connection, the following algorithms are used to process data from sensors: an algorithm for monitoring the smallest and largest values of the indicators; an algorithm for controlling the difference between the largest and the smallest values of indicators; an algorithm for controlling the arithmetic mean; an algorithm for controlling emissions.

The algorithm for controlling the smallest and largest values of indicators has the following form:

1. Obtain the M set of accounting objects of type $t$.

2. Select the accounting object from the set $\mathrm{M}$.

3. For the selected accounting object, compare the current value of the indicator $m$ with the minimum and maximum allowable values for this indicator ( $\max$ and $\min )$.

4. If the value of the indicator $\mathrm{m}>\max$ or $\mathrm{m}<\mathrm{min}$, then place the accounting object in the set $\mathrm{P}_{\mathrm{n}}$. Otherwise, place the accounting object in the set $\mathrm{P}_{\mathrm{m}}$.

5. If the set $\mathrm{M}$ is non-empty, go to step 2 .

6. Output a list of accounting objects from the set $P_{n}$, which failed to pass the control of the smallest and largest values of the indicators. Output a list of accounting objects from the set $\mathrm{P}_{\mathrm{m}}$, which successfully passed the control of the smallest and largest values of the indicators.

The algorithm for controlling the difference between the largest and the smallest values of the indicators is the following:

1. Obtain the M set of accounting objects of type $t$.

2. Select the accounting object from the set $\mathrm{M}$.

3. For the indicator $r$ of the selected accounting object, find the maximum and minimum values $\left(\mathrm{s}_{\max }\right.$ and $\left.\mathrm{s}_{\min }\right)$.

4. Compare the difference module of the found values with the allowable difference between the largest and the smallest values for the exponent $r$.

5. If $\left|S_{\max }-S_{\min }\right|>$ int, then place the accounting object in the $\mathrm{P}_{\mathrm{n}}$ set. Otherwise, place the accounting object in $\mathrm{P}_{\mathrm{r}}$.

6. If the set $\mathrm{M}$ is non-empty, go to step 2 .

7. Output a list of accounting objects from the set $P_{n}$, which failed to control the difference between the largest and the smallest values for the exponent $r$. Output a list of accounting objects from the set $\mathrm{P}_{\mathrm{r}}$, which successfully passed the control of the difference between the largest and the smallest values for the indicator $r$.

The algorithm for controlling the arithmetic mean looks like this:

1. Obtain the M set of accounting objects of type $t$.

2. Select the accounting object from the set M.
3. For the indicator a of the selected accounting object, find the arithmetic mean of its values.

4. Compare the found arithmetic mean with the minimum and maximum admissible values of the arithmetic mean for the indicator $\mathrm{a}\left(\mathrm{a}_{\min }\right.$ and $\left.\mathrm{a}_{\max }\right)$.

5. If $\operatorname{avr}(\mathrm{k}, \mathrm{S})>\operatorname{amax}$ or $\operatorname{avr}(\mathrm{k}, \mathrm{S})<\operatorname{amin}$, then place the accounting object in the set $P_{n}$. Otherwise, place the accounting object in the set $\mathrm{P}_{\mathrm{a}}$.

6. If the set $\mathrm{M}$ is non-empty, go to step 2.

7. Output a list of accounting objects from the set $\mathrm{P}_{\mathrm{n}}$, which failed to control the arithmetic mean of the indicator a. Output a list of accounting objects from the set $\mathrm{Pa}$, which have successfully passed the control of the arithmetic mean of the indicator a.

The algorithm for controlling emissions - the values of indicators that differ sharply from the basic number of values - looks like this:

1. Obtain the M set of accounting objects of type t.

2. Select the accounting object from the set $\mathrm{M}$.

3. For the indicator $g$ of the selected accounting object, find the arithmetic mean of its values except for the current one.

4. Compare the difference between the average arithmetic mean and the current value of $g$ with the allowable emission value for the $\mathrm{g}$ indicator.

5. If $|\operatorname{avr}(h, S)-s h+1|>$ out, then place the accounting object in the set $P_{n}$. Otherwise, place the accounting object in the set $\mathrm{P}_{\mathrm{g}}$.

6. If the set $\mathrm{M}$ is non-empty, go to step 2 .

7. Output a list of accounting objects from the set $P_{n}$, which failed to control the emissions for the indicator $\mathrm{g}$. Output a list of accounting objects from the set of $\mathrm{P}_{\mathrm{g}}$, which successfully passed the emission control for the indicator $\mathrm{g}$.

When using models of fuzzy criteria for checking data, the difference between their algorithms and those described above will be that for accounting objects the value of the membership function will be calculated, which will divide accounting objects into subsets assigned by the function.

Despite a large number of subsystems for data processing and regulation, the operator interface at all levels remained simple and convenient. A snapshot of the window form of the dispatcher control panel installed in the boiler house is shown in Figure 4, and Figure 5 shows the interface of the dispatch center operator from the second level system. The interface of the industrial safety system was not developed; the system launches and runs in fully automated mode.

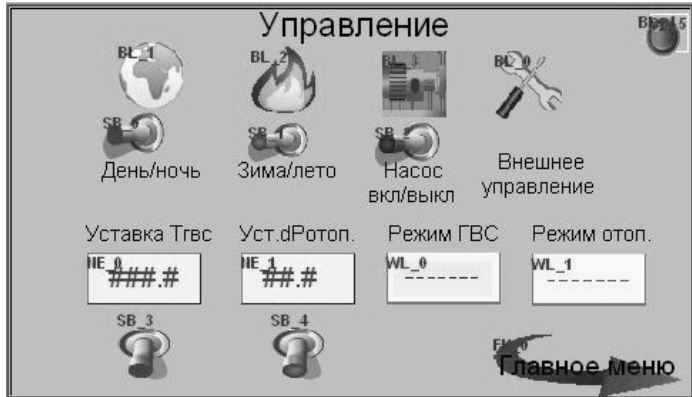

Fig. 4. The interface of the dispatching control panel, the system of the lower one. 


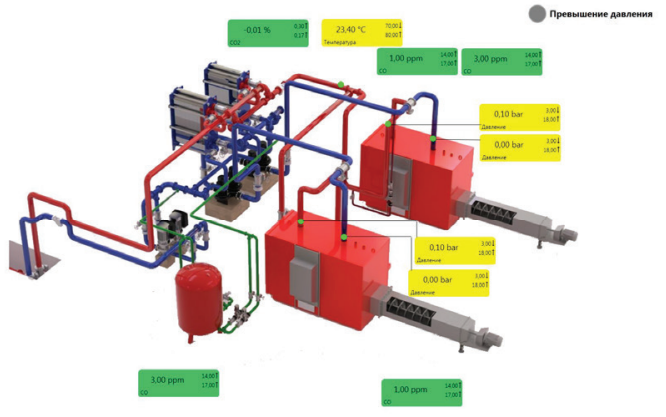

Fig. 5. The interface of the dispatching control panel, the system of the lower one.

\section{Conclusion}

The developed software and hardware complex was installed in the boiler house of the city of Orel. Complex automation took a month of work, but at the same time, a complex shutdown of the boiler house occurred only once per one working day. The carried out complex of works confirms that the development of application systems with improved safety and reliability characteristics is not only an important technical task, but also requires the carrying out of research works.

\section{References}

1. E. L. Palej, Normativnye trebovanija $i$ prakticheskie rekomendacii pri proektirovanii kotel'nyh (Piter, SPb, 2014) [in Russian]

2. Svod pravil SP 89.13330.2012 Kotel'nye ustanovki. Aktualizirovannaja redakcija SNiP II-35-76 (Analitik, Moscow, 2012) [in Russian]

3. A. V. Shhegol'kov, M. A. Mishin, Polzunovskij vestnik, no. 1, 257-265 (2011) [in Russian]

4. A. G. Aleksandrov, M. V. Automatics and telemechanics, no. 2, 16-30 (2014) [in Russian]

5. T. A. Kramina, I. F. Safin, G. A. Zaripova, Proceedings of Kazan state University of architecture and construction, no. 1, 50-54. (2014) [in Russian]

6. V. Polonskij, G. Titov, A. Polonskij, Avtonomnoe teplosnabzhenie, 152 (Izdatel'stvo Associacii stroitel'nyh vuzov, Moscow, 2007) [in Russian]

7. D.V. Paap, Novye tehnologii v teplosnabzhenii $i$ stroitel'stve, no. 8, 293 (2010) [in Russian]

8. Ju. F. Davydov, Vestnik KazahstanskoAmerikanskogo Svobodnogo Universiteta, Issue 6, Ust'-Kamenogorsk,178 (2011) [in Russian]

9. V. A. Nesterov et. al., Vestnik Voronezhskogo gosudarstvennogo universiteta. Serija: Sistemnyj analiz i informacionnye tehnologii, no.1, 77-83. (2014) [in Russian]

10. O. V. Shishov Avtomatizacija i proizvodstvo, no.1, 36-37 (2014) [in Russian]

11. O. V. Shishov, Jelementy sistem avtomatizacii: kontrollery, operatornye paneli, moduli udalennogo dostupa (Direkt-Media, Moscow Berlin, 185, 2015) [in Russian]

12. A. A. Gorjunkova, Ju. I. Okuneva, Prioritetnye napravlenija razvitija nauki $i$ tehnologij, 124 (2015) [in Russian]

13. S.P. Petrov, Analiz i sintez sistemy upravlenija processom peredachi teplovoj jenergii $v$ kogeneracionnoj sisteme centralizovannogo teplosnabzhenija. Monografija (Orlik and K Publishing House, Orel, 314, 2009) [in Russian]

14. K.V. Podmaster'ev, Datchiki i sistemy, no. 6, 1418. (2008) [in Russian]

15. S.P. Petrov, Avtomatizacija kogeneracionnyh sistem teplosnabzhenija $s$ raspredelennymi pikovymi nagruzkami. Monografija (Mashinostroenie, Moscow: 1, 304, 2007) [in Russian]

16. A.V. Pilipenko, Informacionnye sistemy i tehnologii, no. 4/66, 115-119. (2011) [in Russian]

17. K.V. Podmaster'ev, Kontrol'. Diagnostika, no. 5, 45-57 (2010) [in Russian]

18. A.V. Pilipenko, Fundamental'nye i prikladnye problemy tehniki i tehnologii, no. 6-2(296), 58-64. (2012) [in Russian]

19. K.V. Podmaster'ev, Mir Izmerenij, no. 1, 36-41. (2010) [in Russian]

20. S.P. Petrov, Mehatronika, avtomatizacija, upravlenie, no. 5, 46 -53. (2006) [in Russian] 